\title{
The genus Thunbergia in southern Africa*
}

\author{
E. RETIEF** and W, F. REYNEKE ${ }^{+}$
}

Keywords: Acanthaceae, revision, southern Africa, taxonomy, Thunbergia

\author{
ABSTRACT
}

The genus Thunbergia Retz. in southern Africa is revised and eleven species are recognized.

\section{THUNBERGIA}

Thunbergia Retz. in Phys. Saellsk. Handl. 1: 163 (1780, non ' 1776 ') nom. cons. non Thunbergia Montin in K. svenska Vetenskakad. Handl. 34: 288 (1773), nom. rejic.; L.f., Suppl. 292 (1781); Cothenius, Disp. 8: Mai-Jun. (1790) as 'Thunberga'; Poiteau in Revue hort., Paris 2,4: 409 (1845) as 'Thumbergia'; Nees in DC., Prodr. 11: 54 (1847); Benth. \& Hook. f., Gen. Pl. 2: 1072 (1886); Baill., Hist. Pl. 10: 423 (1891); Lindau in Natürl. PflFam. 4,36: 291 (1895); Burkhill \& Clarke in Fl. Trop. Afr. 5: 8 (1899); C.B. Cl. in Fl. Cap. 5,1: 3 (1912); Bailey, Cycl. Hort. 3337 (1929); Phill., Gen. 700 (1951); Chittenden in Dict. Gard. 2105 (1951); Heine in Fl. W. Trop. Afr. 2 (edn 2): 392 (1963); Melchior in Engl., Syll. PflFam. 2 (edn 12): 458 (1964); Heine in Flora Gabon 13: 58 (1966); Benoist in Fl. Madag. 182: 9 (1967); P.G. Meyer in Prodr. Fl. S.W. Afr. 129 (1968); Long in J. Arnold Arbor. 51: 273 (1970); Ross, Fl. Natal 321 (1972); R.A. Dyer, Gen. Sthn Afr. Pl. 1: 585 (1975); Compton, Fl. Swaz.: 546 (1976). Type species: T. capensis Retz.

Diplocalymma Spreng., Neue Entd. 3: 30 (1822).

Heksacentris Nees in Wall., Pl. Asiat. Rar. 3: 78 (1832).

Endomelas Rafin. in Fl. Tellur. 4: 67 (1836).

Pleuremidis Rafin. in Fl. Tellur. 4: 67 (1836).

Schmidia Wight. in Ic. Pl. Ind. Orient.: t.1848 (1852).

Herbs or herbaceous creepers; rootstock present or absent; epigaeous organs sparsely to densely hairy. Trichomes unbranched, uni- or multi-cellular; glandular trichomes stipitate with heads panduriform or pinshaped. Stems laterally grooved, square, cylindric or ribbed; unbranched or monopodially branched. Leaves simple, decussate, sessile or petiolate; petioles sometimes winged, basal part somewhat swollen; blade linear, lanceolate, ovate or elliptic, apex emarginate, rounded, obtuse or attenuate, base hastate, auriculate, cordate,

*Partly based on an M.Sc. thesis, University of Pretoria.

**Botanical Research Institute, Department of Agriculture, Private Bag X101, Pretoria 0001.

+Department of Botany, University of Pretoria, Hillcrest, Pretoria 0002. rounded or obtuse or acute, margin entire, lobed or toothed, veins looped or parallel to apex, main vein and some lateral veins ending in a mucro (Fig. 1). Stipules absent. Flowers axillary, zygomorphic, bisexual, pedunculate, subtended by 2 bracts. Flower bracts 2, sessile, opposite, caducous or persistent, enlarged sometimes to protect fruit, ovate, boat-shaped, keeled, base cordate. Calyx persistent, connate at the base, usually with $10-16$ subuliform lobes, unequal in length. Corolla gamopetalous, tube cylindric at base, infundibuliform in the upper part; 5-lobed, lobes obovate or sometimes nearly triangular, contorted; inner and outer surface of lobes and outer surface of tube white, shades of yellow, orange or purplish-blue; inner surface of tube shades of yellow, yellowish green or dark purplish black; one-celled trichomes sometimes present, as well as stipitate glands. Stamens 4; included, didynamous, inserted at the base of the infundibuliform part of the tube. Filaments broad at the base, linear dorsifixed, connective ending in an apiculum, multicellular hairs present at base. Anthers 2-thecous; thecae of long stamens equal, spurred, with trichomes nearly along the whole length of the cleft and concentrated at the base; thecae of short stamens unequal, the longest one with trichomes along the whole length of the cleft, spurred, the other one with trichomes only at the base, spurs absent or rudimentary; spurs unbranched in exceptional cases, branched at apex (Fig. 2). Gynoecium superior, included, ovary 2-locular with two axile ovules per locule; style cylindric; stigma funnel-shaped or 2-lobed, usually with one lobe above the other (Fig. 3). Disc present, annular, fleshy. Fruit a capsule, globose, beaked, loculicidal dehiscent, trichomes present or absent; fruit stalk, sometimes swollen (Fig. 4). Seed semi-globose with a cavity on the side of the hilum; testa brown to greyish black, pubescent, trichomes homogeneously distributed or adhering to form different patterns on the testa (Figs $5 \& 6$ ).

In 1773 Montin described the genus Thunbergia in Rubiaceae. In 1780 Raetzius, aware of Thunbergia Montin, used the same generic name for describing species of Acanthaceae collected by Thunberg at the Cape, hence Thunbergia Retz. was a later homonym and therefore illegitimate. Later authors such as the younger Linnaeus (1781) did not attribute Thunbergia to Retzius, and Lindau (1893) and C.B. Clarke (1912) actually attributed the name to Linnaeus fil. Fortunately the problem has been resolved by 

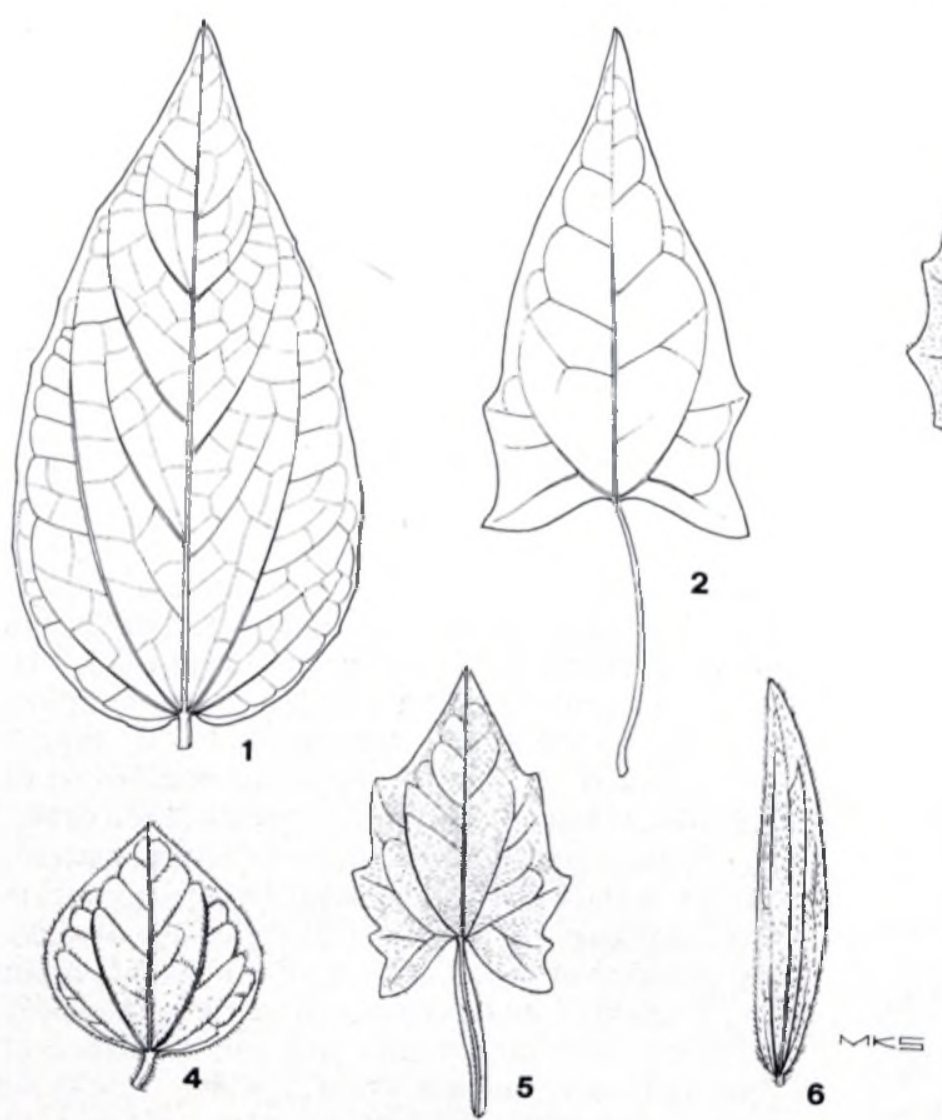
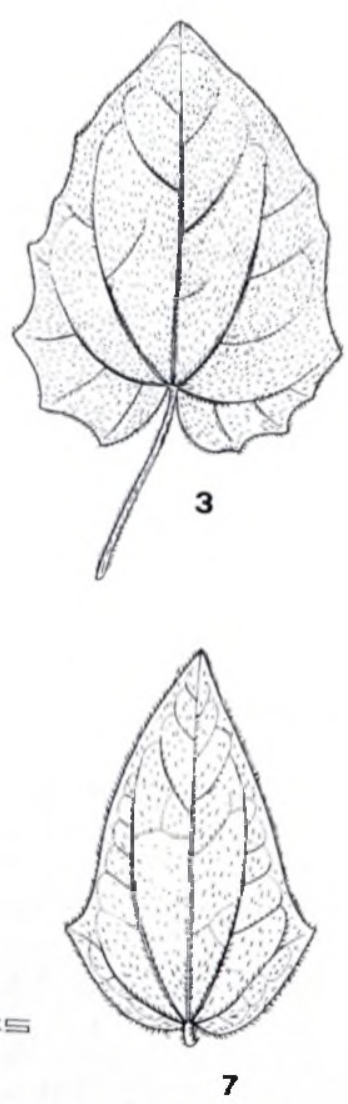

FIG. 1.-Variation of leaf base in Thunbergia, $\times 0,5.1, T$. natalensis (Retief 220); 2, T. purpurata (Retief 213); 3, T. amoena (Retief 178); 4, T. capensis (Retief 254); 5, T. aurea (Van Greuning 246); 6 , $T$. venosa (Stirton 347). conservation of Thunbergia Retz. against Thunbergia Montin with $T$. capensis Retz. as the type species of the conserved name (ICBN, p. 396, 1978).

The presence of conspicuously large bracts concealing the saucer-shaped calyx with its toothlike lobes, panduriform glandular hairs, the structure of the corolla, the fruit being a globose capsule with a prominent, ensiform beak and the absence of retinacula are important features characterizing the genus Thunbergia.

The species of Thunbergia, indigenous in southern Africa, occur in grassveld, thornveld, bushveld, along the margins of forests or in false fynbos as creepers, shrublets or herbs. Although certain herbaceous creepers like $T$. dregeana, T. amoena and $T$. purpurata are usually part of the undergrowth of forests and wooded areas, the species are not
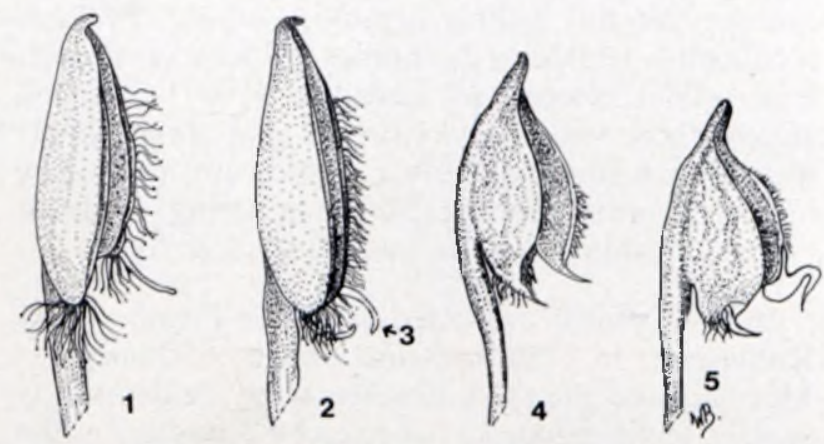

FIG. 2.-Different anther types in Thunbergia, $\times 6.1$, part of a short stamen with anther locules different in length, $T$. alata 2, part of a long stamen with anther locules more or less the same length, $T$. alata; 3 , spur; 4 , part of a long stamen with anther locules more or less the same length, $T$. natalensis; 5 , part of a short stamen with anther locules different in length, T. natalensis. restricted to shady and moist places, but do occur in the open.

1. Thunbergia natalensis Hook. in Curtis's bot. Mag. 24: t.5082 (1858); Anderson in J. Linn. Soc., Bot. 7: 18 (1864); Wood in Trans. S. Afr. phil. Soc. 204 (1909); C.B. Cl. in Fl. Cap. 5,1: 4 (1912); Bews, Fl. Natal \& Zululand 192 (1921); Phill. in Flower. Pl. Afr. 4: t.147 (1924); Bailey, Cycl. Hort.: 3339 (1929); Chittenden in Dict. Gard. 2106 (1951); Hulme, Wild Flow. Natal t.5, f. 10 (1954); Eliovson, S. Afr. Flow. for the Garden 274 (1955); Batten \& Bokelmann, Wild Flow. E. Cape 135 (1966); Ross, Fl. Natal 323 (1972); Kruger, Bome, Struike \& Rankplante 514 (1973); Agnew, Upland Kenya Wild Flow. 578 (1974); Gibson, Wild Flow. Natal t.97, f. 4 (1975); Jeppe, Natal Wild Flow. 93 (1975); Compton, Fl. Swaz. 547 (1976). Type: Natal, collector unknown (K, holo.!; PRE, photo!).
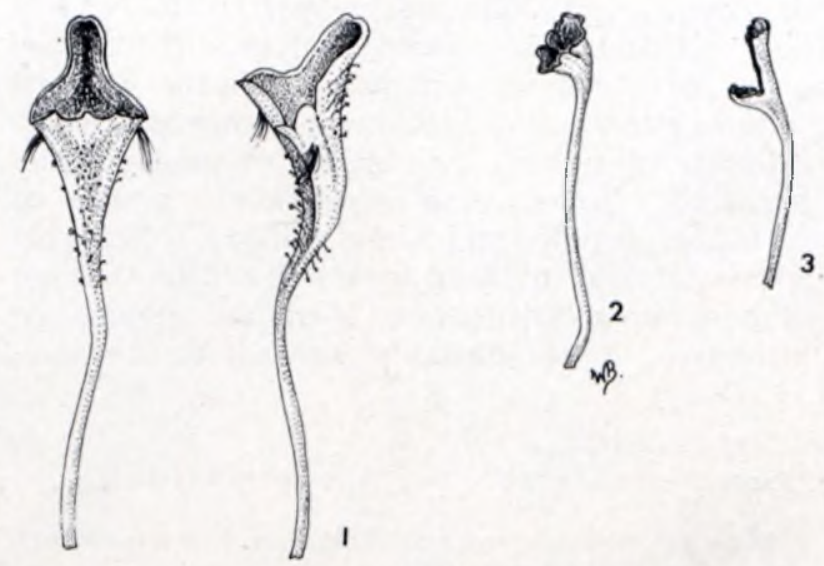

FIG. 3. - Stigmas and styles in Thunbergia, $\times 2,5.1, T$. natalensis, stigma funnel-shaped; $2, T$. capensis, stigma lobed; $3, T$. alata, stigma lobed. 


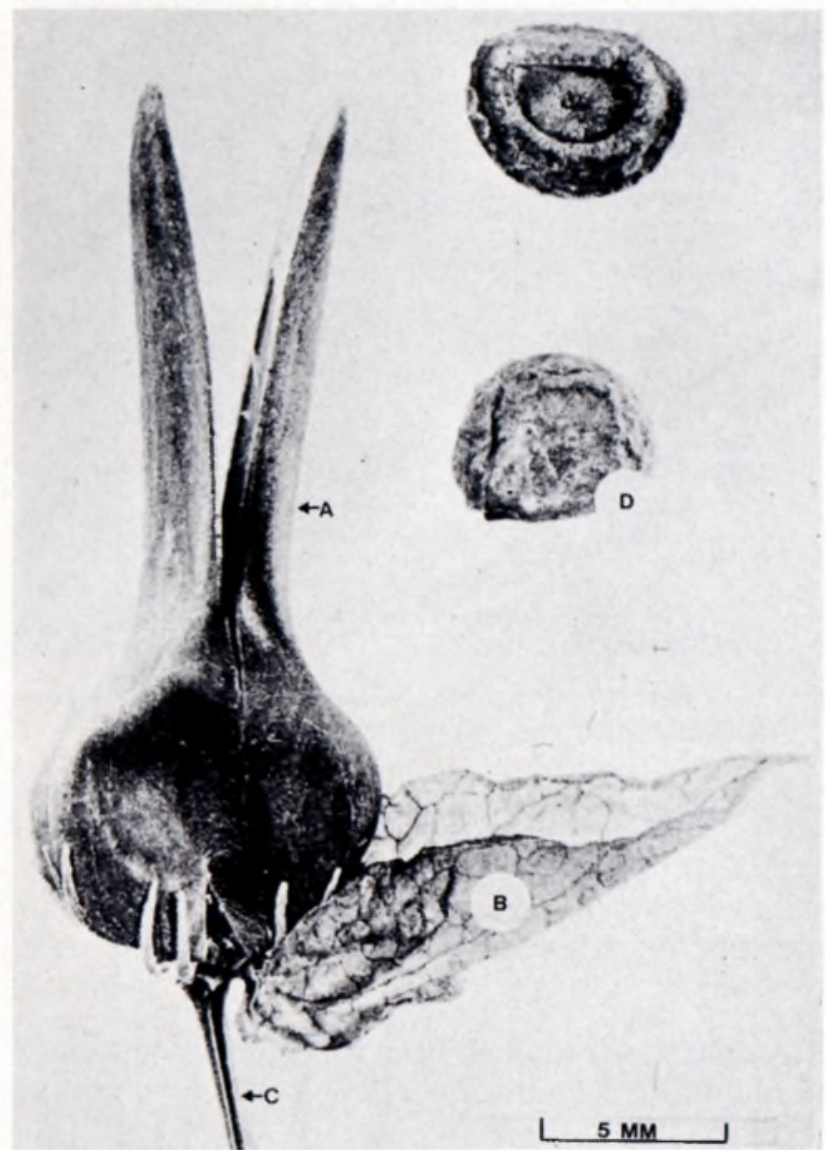

FIG. 4.-Flower parts of Thunbergia purpurata; A, carpel; B, bract; C, part of fruit stalk; D, seed.

Dwarf shrub, herbaceous, $\pm 0,75-1 \mathrm{~m}$ high; stems puberulous. Leaves sessile or with petioles up to $28 \mathrm{~mm}$ long; blade elliptic to ovate, (21-) 55-110 $(-159) \times(15-) 35-70(-82) \mathrm{mm}$, apex acute, base cordate, margin entire, lobed or toothed. Flower bracts $17-27 \times(10-) 12-15(-20) \mathrm{mm}$, light green with conspicuous venation; with pin-like glands, \pm 1 $\mathrm{mm}$ long, caducous. Calyx 1,5-6 mm long; connated at the base, unequally shortly lobed; unicellular trichomes present. Corolla with lobes $12-17 \times 13-20 \mathrm{~mm}$, lobes light blue to purplish blue; tube $23-31 \mathrm{~mm}$ long and $2-18 \mathrm{~mm}$ in diameter, inside yellow to white with purplish blue to light blue stripes running from the lobes, outside light blue to purplish blue. Filaments $7-10 \mathrm{~mm}$ long, with stipitate glands, anther thecae 2,2-3,2 mm long, spurs conspicuously curved. Style $13-17 \mathrm{~mm}$ long with pin-like glands. Stigma funnel-shaped with pin-like glands and lateral clusters of multicellular trichomes. Fruit pubescent; 21-30 mm long, globose base $8-17 \mathrm{~mm}$ in diameter; stalk $(26-)$ $35-76(-89) \mathrm{mm}$ long. Seed reddish-brown; surface ridged; $4,5-6,5 \mathrm{~mm}$ in diameter.

Found in shade along the margins of forests and woodland or pine plantations, rarely in direct sunlight. Recorded from the Transkei, Natal, Swaziland, Transvaal and northwards to Kenya (Fig. 7).

T. natalensis is characterized by its growth form, purplish blue corolla, the curved spurs of the anthers and a funnel-shaped stigma. The species flowers from October to March.

The 'Natal Blue Bell' is found growing in gardens. Bor \& Raizada (1941) mention that $T$. natalensis occurs in gardens throughout India. According to J. Erens (pers. comm., 1976) the species can easily be propagated by means of cuttings.

2. Thunbergia venosa C.B. Cl. in Fl. Cap. 5,1: 6 (1912); Bews, Fl. Natal \& Zululand 192 (1921); Hulme, Wild Flow. Natal t.12, f.11 (1954); Ross, Fl. Natal 323 (1972). Types: Natal, Itafamasi, Wood 643 (K, lecto.!; BOL!; NH!; PRE, photo!; SAM).

\section{KEY TO SPECIES}

Herbaceous shrublets or single-stemmed herbs:

Shrublet, $0,75-1 \mathrm{~m}$; corolla purplish blue; stigma funnel-shaped

1. T. natalensis

Shrublet, $0,25-0,4 \mathrm{~m}$ or a single-stemmed herb, 0,09-0,3 $\mathrm{m}$; stigma 2-lobed, one lobe below the other:

A single-stemmed herb; leaf blade narrowly ovate

2. T. venosa

A herbaceous shrublet; leaf blade ovate to broadly ovate .

3. T. atriplicifolia

Herbaceous climbers (sometimes rather a scrambler):

Leaves with petioles not winged; fruit glabrous or sparsely pubescent:

Leaves sessile or with petioles less than $8 \mathrm{~mm}$; anther thecae not spurred

4. T. capensis

Leaves with petioles usually longer than $8 \mathrm{~mm}$; anther thecae spurred (if not, then leaf base hastate):

Leaf base hastate:

Leaf with veins on abaxial side dark purple

5. T. purpurata

Leaves not as above

6. $T$. pondoensis

Leaf base cordate:

Flowers white

7. T. neglecta

Flowers dull orange or lemon-yellow:

Leaves densely pubescent, flowers lemon-yellow (Transvaal)

8. T. amoena

Leaves sparsely pubescent, flowers dull orange (Natal, Cape Province)

9. T. dregeana

Leaves with petioles winged; fruit densely pubescent:

Inner surface of corolla tube dark purplish black, corolla orange; seeds with trichomes adhering in wing-like protuberances ...........................................................................10. T. alata

Inner surface of corolla tube dull white, corolla dull orange; seeds with trichomes adhering in papillae-like protuberances 


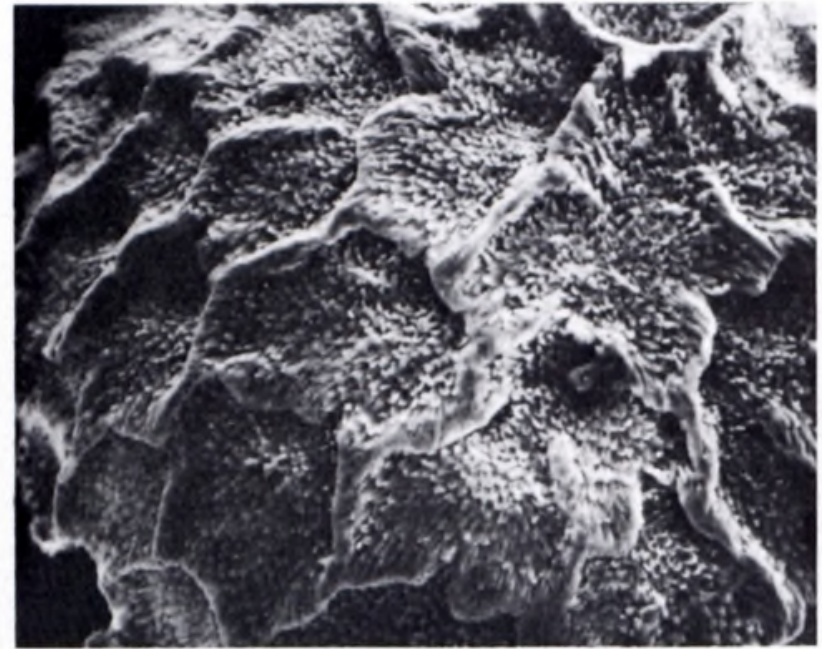

FIG. 5.-Part of the seed surface of Thunbergia pondoensis where the trichomes adhere to form ridges, $\times 42$.

Herb, sparsely to densely pubescent; trichomes on stem, yellowish brown. Leaves sessile; blade linear to lanceolate, (14-) 30-77 $\times(4-) 7-30 \mathrm{~mm}$, apex acute, base cordate, margin entire or with a few teeth, main vein and lateral veins raised on under surface. Flower bracts (18-) 20-25 × (8-) 16-20 $\mathrm{mm}$, longer than mature fruit. Calyx covered with stipitate glands having one stalk cell and multicellular trichomes; lobes 2,5-4,8 mm long. Corolla with inner and outer surface of lobes and outer surface of tube yellow, inside of tube dull yellow; lobes 9,5-14 $\times 11-20 \mathrm{~mm}$, tube $23-21 \mathrm{~mm}$ long and $2,4-11 \mathrm{~mm}$ in diameter. Filaments $3-4,6 \mathrm{~mm}$ long; anther thecae 3-4,2 mm long. Style 11-13 mm long; unicellular trichomes present on upper part. Fruit glabrous; $15-25 \mathrm{~mm}$ long; globose base $6-10 \mathrm{~mm}$ in diameter; stalk $45-60 \mathrm{~mm}$ long. Seed reddish brown; surface with prominent ridges; $2,6-4,6 \mathrm{~mm}$ in diameter.

$T$. venosa is found in grassland where it occurs in open sunlight. The species is endemic in Natal (Fig. 8).

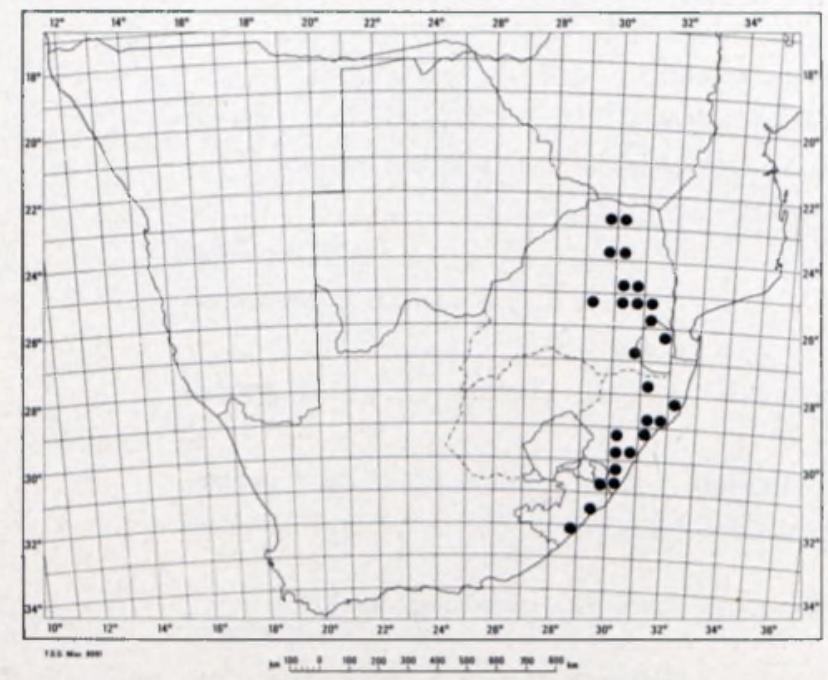

FIG. 7.- - Thunbergia natalensis.

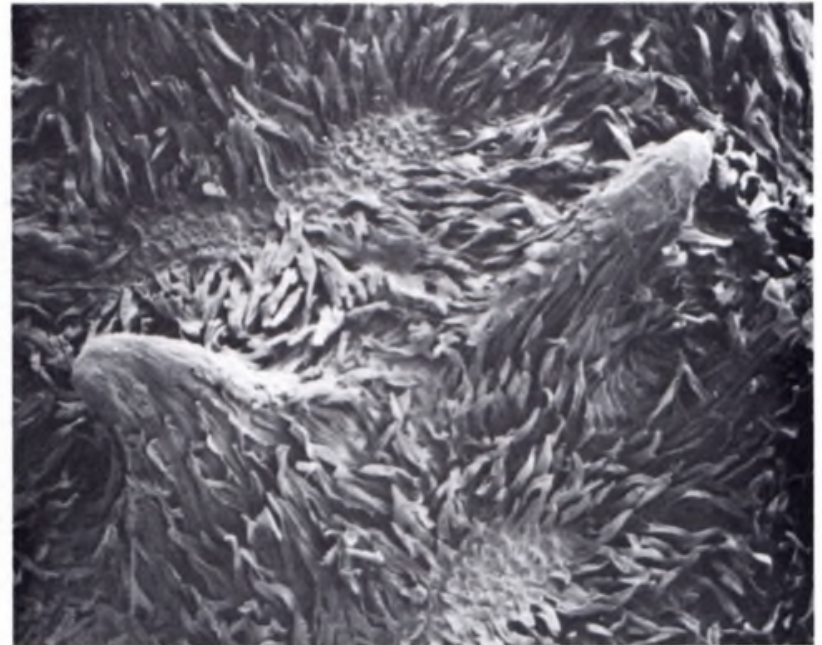

FIG. 6.-Part of the seed surface of Thunbergia aurea with patches where no trichomes occur, $\times 56$.

It is distinguished from related taxa by its single stem with slender, sessile leaves, densely crowded in the upper part. The species flowers from September to April.

A decoction obtained from the minced roots of $T$. venosa is used by the Zulu people as a love-potion (Hulme, 1954).

3. Thunbergia atriplicifolia E. Mey. ex Nees in DC., Prodr. 11: 56 (1847); Anderson in J. Linn. Soc., Bot. 7: 20 (1864); Sim, Fl. Kaffraria 61 (1894); Wood in Trans. S. Afr. phil. Soc. 203 (1909); Wood, Natal Plants t.594 (1912); C.B. Cl. in Fl. Cap. 5,1: 7 (1912); Bews, Fl. Natal \& Zululand 192 (1921). Hulme, Wild Flow. Natal t.12, f. 11 (1954); Letty, Wild Flow. Trans. 313 (1962); Batten \& Bokelmann, Wild Flow. E. Cape 140 (1966); Van der Schijff, Checklist Kruger Nat. Park: 86 (1969); Gledhill, E. Cape Veld Flow. 214: t.57, f. 7 (1971?); Ross, Fl. Natal 323 (1972); Gibson, Wild Flow. Natal t.97, f. 2 (1975); Jeppe, Natal Wild Flow. 92 (1975);

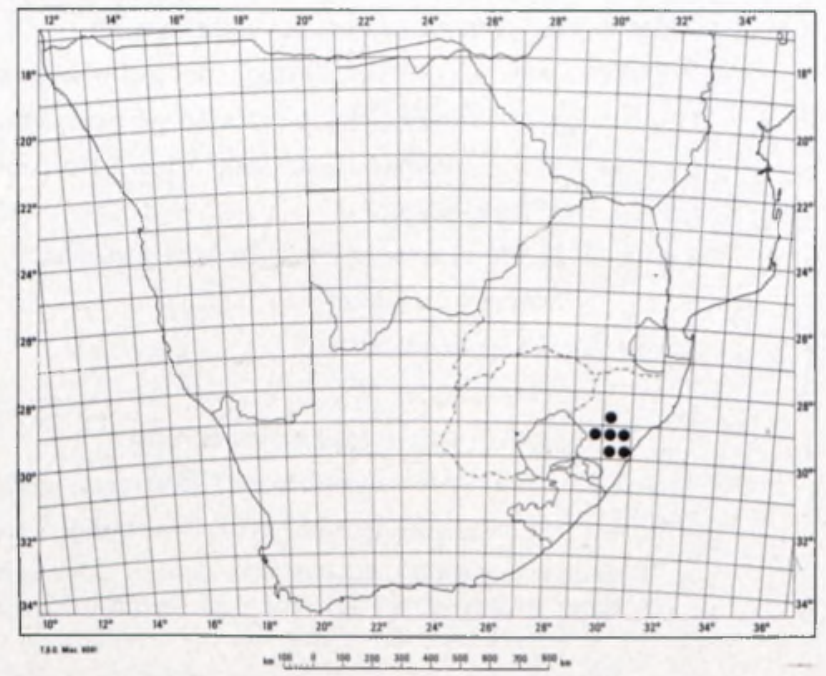

FIG. 8.- - Thunbergia venosa. 
Compton, Fl. Swaz. 546 (1976). Type: Cape Province, Kei River near Komga, Drège s.n. (K., lecto.!; PRE, photo!).

T. aspera Nees in DC., Prodr. 11: 56 (1847); Sim, Fl. Kaffraria 61 (1894); Wood in Trans. S. Afr. phil. Soc. 18: 203 (1909); C.B. Cl. in Fl. Cap. 5,1: 8 (1912); Bews, Fl. Natal \& Zululand 192 (1921); Ross, Fl. Natal 323 (1972). Type: Cape Province, Transkei, Gill s.n. (K, holo.!; PRE, photo!).

T. aspera Nees var. parvifolia Sond. in Linnaea 23: 90 (1850); C.B. Cl. in Fl. Cap. 5,1: 8(1912). Type: Transvaal, Magaliesberg, Zeyher 1418 (K, lecto.!; PRE, photo!).

T. bachmannii Lindau in Bot. Jb. 17: 94 (1893); Lindau, l.c. (Beibl. 41): 38,41 (1893); C.B. Cl. in Fl. Cap. 5,1: 8 (1912); Compton, Fl. Swaz. 546 (1976). Type: Transkei, sin. loc., Bachmann 1267 (K, lecto.!; PRE, photo!).

T. baurii Lindau in Bot. Jb. 24: 312 (1898). Type: 'Cape Province', Baziya, Baur 169 (K, holo.!; PRE, photo!).

T. flavohina Lindau in Bot. Jb. 24: 311 (1898). Type: "Cape Province' Baziya, Baur 58 (K, holo.!; PRE, photo!).

T. galpinii Lindau in Bot. Jb. 24: 310 (1898); C. B. Cl. in Fl. Cap. 5,1: 6 (1912). Type: Transvaal, Saddleback Mountain, Galpin 1277 (K, holo.?; PRE!).

T. xanthotricha Lindau in Bot. Jb. 24: 311 (1898); C.B. Cl. in Fl. Cap. 5,1: 8 (1912); Bews, Fl. Natal \& Zululand: 192 (1921); Van der Schijff, Checklist Kruger Nat. Park 86 (1969). Type: Transvaal, Barberton, Galpin 496 (K, holo.!; BOL!; PRE!; SAM!).

T. atriplicifolia Nees var, kraussii C.B. Cl. in Fl. Cap. 5,1: 7 (1912). Type: Natal, sin. loc., Krauss 405 (K, holo.!; PRE, photo!).

T. bachmannii Lindau var. minor C.B. Cl. in Fl. Cap. 5,1: 8 (1912). Type: sin. loc., Cooper 893 (K, holo.!; BOL!; PRE, photo!).

T. cordibracteolata C. B. Cl. in Fl. Cap. 5,1: 7 (1912). Type: $\sin$. loc., Cooper 895 (BOL, iso.!; PRE, photo!).

T. hirtistyla C.B. Cl. in Fl. Cap. 5,1: 7 (1912); Bews, Fl. Natal \& Zululand 192 (1921); Ross, Fl. Natal 323 (1972). Type: Natal, sin. loc., Gerrard 1274 (K, holo.!; NH!; PRE, photo!).

Shrublet, $0,25-0,4 \mathrm{~mm}$ high, sparsely to densely pubescent. Stems with a tendency to twine. Leaves sessile or with petioles up to $4 \mathrm{~mm}$ long; blade ovate, elliptic to lanceolate, $(10-) 23-62(-80) \times(6-)$ $12-35(-55) \mathrm{mm}$, apex acute, obtuse or emarginate, base cordate, truncate or cuneate, margin entire or toothed, usually only with two teeth at the base. Flower bracts persistent, (13-) 17-27 mm long. Calyx 3-5 mm long and (8-) 10-17 $\mathrm{mm}$ broad. Corolla with inner and outer surface of lobes and outer surface of tube dull white, inner surface of tube dull yellow; lobes $(10-) 13-17(-20) \times(11-)$ $15-29 \mathrm{~mm}$, tube $20-27(-32) \mathrm{mm}$ long and $(1,7-)$ $2-10 \mathrm{~mm}$ in diameter with unicellular trichomes and stipitate glands. Filaments 4-6,5 mm long; anther thecae 3-4 mm long. Style 11-16 $\mathrm{mm}$ long, upper part pubescent or glabrous. Fruit (13-) 15-19 mm long with globose base (6-) 7-10 $\mathrm{mm}$ in diameter; stalk (26-) 32-78 (-104) mm long. Seed reddish or greyish brown with trichomes usually evenly arranged; $3,8-6 \mathrm{~mm}$ in diameter.

T. atriplicifolia is found as a subordinate species in grassland where it flourishes in both loam and sandy soil. The species has a wide distribution, occurring in the Transvaal, Swaziland, Natal, Transkei and the Cape Province (Fig. 9).

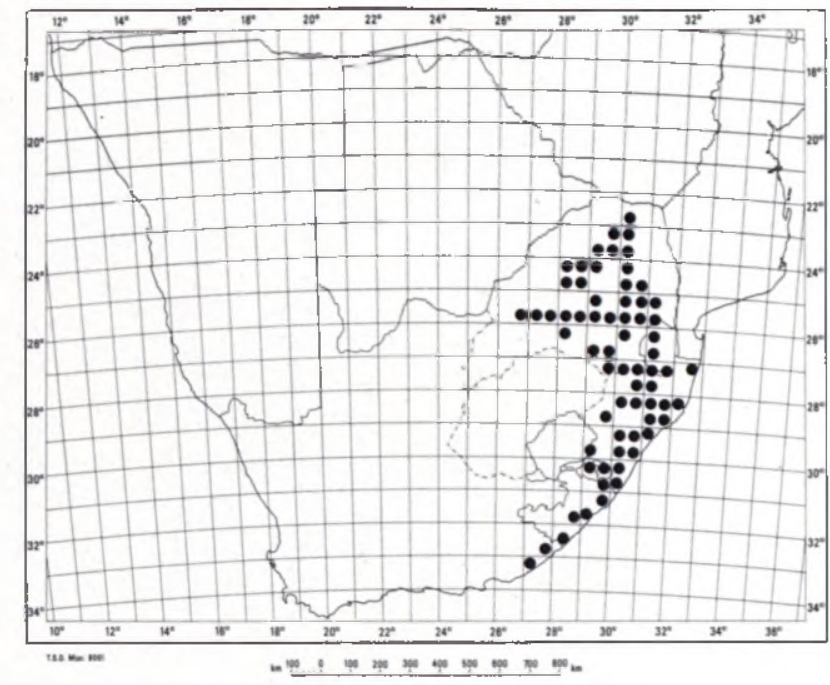

FIG. 9.- - Thunbergia atriplicifolia.

The species is very variable and occurs in different habitats: it is not only found inland, but also in grassveld close to the sea.

Lindau (1898) who described T. bachmannii, $T$. xanthotricha and $T$. flavohirta mentions that these three species might be varieties of one species, namely $T$. atriplicifolia and that they needed further investigation. Clarke (1912) in his revision of the genus also indicates that it is an open question whether it is not better to regard the species $T$. bachmannii, $T$. xanthotricha and $T$. aspera as conspecific. In 1864 Anderson cited $T$, aspera as a synonym of $T$. atriplicifolia. Clarke (1912) used leaf shape, pubescence of the style and the form of the flower bracts, to distinguish $T$. atriplicifolia, $T$. aspera, $T$. cordibracteolata, $T$. bachmannii, $T$. hirtistyla and T. xanthotricha. The range of variation within this species complex is very marked. However, as extreme forms are linked by numerous intermediates no formal subdivisions are upheld here. Variation of the leaf blade within the species is shown on Fig. 10.

Where the distribution areas of Thunbergia atriplicifolia and $T$. capensis overlap, plants occur pointing to hybridization of gene-flow between the two species. Such specimens were in the past identified either as $T$. atriplicifolia or $T$. capensis. The leaves of the plants look like those of $T$. capensis only larger, whereas the flowers resemble those of $T$. atriplicifolia. The following specimens are examples of such intermediate plants:

TRANSKEI-3228 (Butterworth): Mazeppa Bay (-BC), Story 4463 (PRE); Kei Mouth (-CB), Flanagan 552 (GRA, PRE, SAM); Bulura River Mouth (-CC), Acocks 15799 (PRE).

According to Batten \& Bokelmann (1966), the Xhosa people prepare a love-potion from the roots and leaves of the plants and Watt \& BreyerBrandwijk (1962) mention that the leaves of $T$. atriplicifolia are used to make a hairwash. The 'species is known as 'Natal Primrose' or 'Cape Primrose'.

4. Thunbergia capensis Retz. in Phys. Saellsk. Handl. 1, 3: 164 (1776); L.f., Suppl. 292 (1781); 


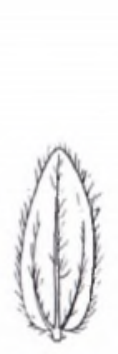

I

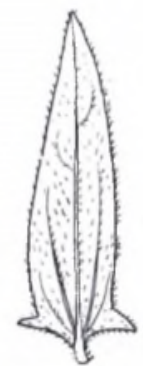

2

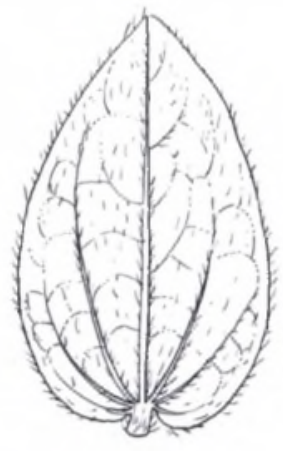

3

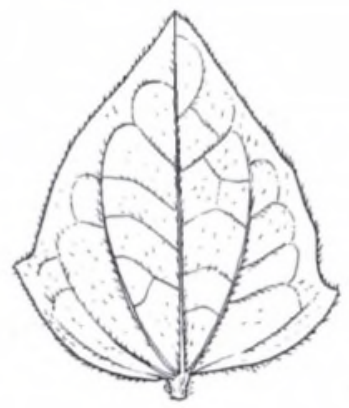

4

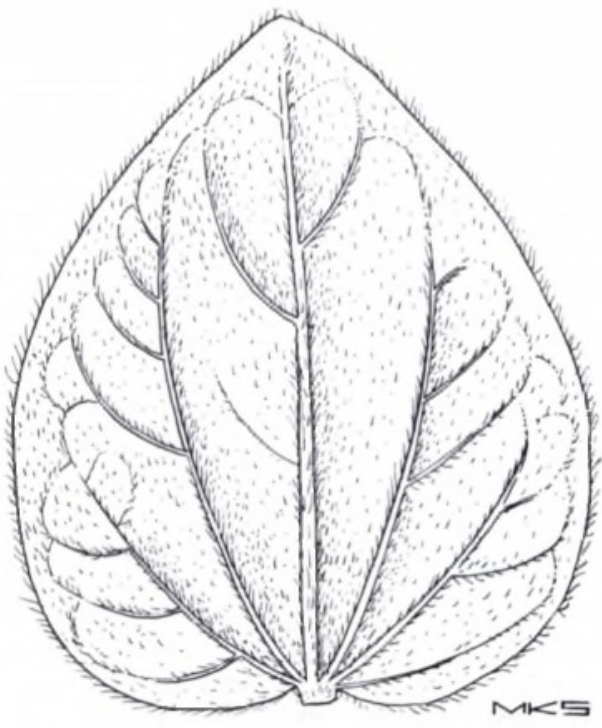

5

FIG. 10.-Variation of leaf shape in Thunbergia atriplicifolia, $\times 0,75,1$, De Sousa 431; 2, Retief 192; 3, Retief 120; 4, Retief 222; 5, Pott 5656.

Thunb., Nov. Gen. Pl. 1: 21 (1781); Thunb., Prodr. 106 (1800); Lam., Encycl. 7: 637 (1806); Lam., Tabl. Encycl. 3: 97, t.549 (1819); Thunb. Fl. Cap. (edn 2): 488 (1823); Lodd., Bot. Cab. t.1529 (1829); Nees in Linnaea 15: 351 (1841); Drège, Zwei Pfl. Doc. 137, 226 (1843); Krauss, Flora: 136 (1846); Nees in DC., Prodr. 11: 55 (1847); Anderson in J. Linn. Soc., Bot. 7: 20 (1864); Lindau in Bot. Jb.: 17 (beibl. 41): 36, 39 (1893); Sim, Fl. Kaffraria 61 (1894); C.B. Cl. in Fl. Cap. 5,1: 5 (1912); Marloth, Fl. S. Afr. 3: 170 (1932); Fourcade, Check list Flow. Pl. George, Knysna, Humansdorp \& Uniondale 6 (1941); Chittenden in Dict. Gard. 2105 (1951); Martin \& Noel, Fl. Albany \& Bathurst 100 (1960); Batten \& Bokelmann, Wild Flow. E. Cape 135 (1966). Type: Cape Province, Thunberg in Herb. Thunb. 14601 (UPS, lecto.; PRE, microfiche!; LUND!).

Scrambler, greyish green, pubescent. Stems prostrate, twining or erect. Leaves sessile or shortly petiolated; petioles up to $7,5 \mathrm{~mm}$ long; blade ovate to reniform, $15-33(-50) \times 14-38(-47) \mathrm{mm}$, apex acute, obtuse or emarginate, base cordate, cuneate or truncate, margin lobed or emarginate, trichomes on upper surface orientated in the same direction. Flower bract 10-16 $\times 8-13 \mathrm{~mm}$. Calyx covered with short stipitate glands and unicellular trichomes; lobes 2,5-4,4 $\mathrm{mm}$ long. Corolla with the inner and outer surface of the lobes and the outer surface of the tube as well as part of the inner surface of the tube yellowish green, bottom part of tube on inner surface dull yellowish green; lobes 7-9 (-18) $\times 3-6$ $(-15) \mathrm{mm}$, tube $12,3-13,5(-20) \mathrm{mm}$ long and $2-7$ $(-10) \mathrm{mm}$ wide. Filaments $3-5,5(-15) \mathrm{mm}$ long; anther thecae without spurs or only one locule of long stamens spurred, thecae 1,5-2 (-4) mm long. Style 7,5-8 (-12) mm long. Fruit 11,3-24 mm long with bulbous base $6-11 \mathrm{~mm}$ in diameter; stalk (18-) 25-62 (-98) mm long. Seed brown; some trichomes adhere to form comb-like protuberances; 3,2-5 mm in diameter.
$T$. capensis flourishes not only on sandy soil in grassland along the coast, but occurs also in stony soil of false fynbos as found in the Ecca Pass area. $T$. capensis is endemic to the Cape Province and the Transkei (Fig. 11).

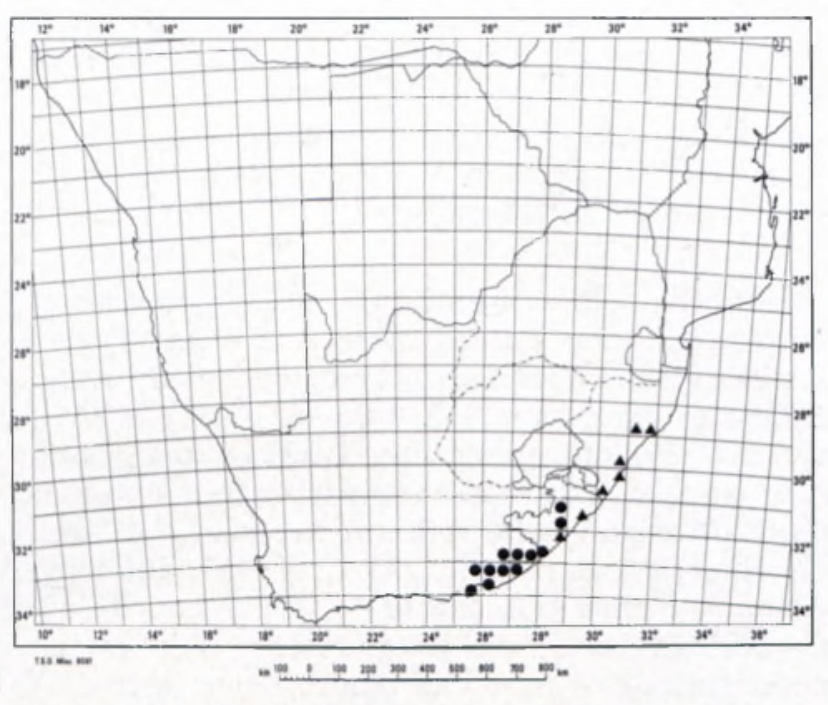

FIG. 11.- - Thunbergia capensis; $\mathbf{\Lambda}, T$. purpurata.

The plant is characterized by broadly ovate leaves with apices acute, obtuse or emarginate, the greenish yellow colour of the corolla and the anther thecae not being spurred. The flowering period of $T$. capensis is from October to April.

The species is suspected of hybridizing with $T$. atriplicifolia where their areas overlap (see $T$. atriplicifolia). Specimens of $T$. capensis with erect stems and flowers nearly double the normal size were collected near Hayes railway halt between Grahamstown and Port Alfred. On investigation they were found to have a triploid chromosome number. 
Leaves of this species mixed and crushed with those of a species of Clematis and Ziziphus mucronata Willd. subsp. mucronata are applied to glandular swellings (Batten \& Bokelmann, 1966).

5. Thunbergia purpurata Harv. ex C.B. Cl. in Fl. Cap. 5,1: 5 (1912); Bews, Fl. Natal \& Zululand 192 (1921); Ross, Fl. Natal 323 (1972). Type: Natal sin. loc., Sanderson 442 (Herb. Hook. K, lecto.!; PRE, photo!).

A dark green, herbaceous creeper, sparsely pubescent. Stems purplish green where internodes thicken; nodes hairy, a few trichomes present on nodes. Leaves with veins on abaxial side dark purple; petiolate, petioles (11-) 18-47 mm long; blade lanceolate $(21-) 46-78(-90) \times(11-) 18-37$ $(-47) \mathrm{mm}$, apex usually acuminate, sometimes obtuse or emarginate; base hastate, margin entire. Flower bracts $13-23 \times 8-20 \mathrm{~mm}$. Calyx with unicellular trichomes and stipitate glands; lobes 1,3-4,7 mm long. Corolla with inner and outer surface of lobes and outer surface of tube white, tube dull yellow on inner surface; lobes 9-13 $\times$ $10,5-13 \mathrm{~mm}$, tube $20-25 \mathrm{~mm}$ long, $2,5-8 \mathrm{~mm}$ in diameter. Filaments $4-6,5 \mathrm{~mm}$ long; anther thecae $3,5-3,7 \mathrm{~mm}$ long, spurs not strongly developed. Style $11-14 \mathrm{~mm}$ long. Fruit $22-25 \mathrm{~mm}$ long, globose base $8-10 \mathrm{~mm}$ in diameter; stalk $30-52 \mathrm{~mm}$ long. Seed reddish brown; some trichomes adhere to form comb-like protuberances; $4,5-7 \mathrm{~mm}$ in diameter.

$T$. purpurata is usually found along the margins of forests or in open parts in the tropical coastal forests. The species occurs only along the coast of Natal and the Transkei as far south as the Kei River (Fig. 11).

It is distinguished from related species by its dark green leaves with conspicuously dark purplish veins on the under surface. The species flowers from November to March.

In 1827 Hooker published a drawing and a description of $T$. angulata Hils. \& Boj. ex Hook., endemic in Madagascar, with a separate drawing of an anther that was from a Thunbergia species of the Cape (Clarke, 1912). T. angulata is not found along the coast of southern Africa as maintained by Hooker and also Anderson (1864) and Lindau (1893). The anther could, according to Clarke (1912), belong to $T$. purpurata described later on. The two species can easily be distinguished by the anther thecae which, in $T$. purpurata, are not spurred or weakly so, the leaf base of $T$. purpurata is hastate and not cordate, whereas the corolla of the species is white and not purple.

6. Thunbergia pondoensis Lindau in Bot. Jb. 17: 93 (1893); Lindau l.c. (beibl. 41): 41 (1893); Wood, Natal Plants 4: t.340 (1906); Wood in Trans. S. Afr. phil. Soc. 18: 204 (1909); Bews, Fl. Natal \& Zululand 192 (1921); Ross, Fl. Natal 323 (1972). Type: Natal, Backbeach, Durban, Bachmann 1265 (Bt); Inyesane, Wood 4015 (NH, lecto.!; PRE, photo!).

Herbaceous creeper, pubescent. Leaves petiolate, petioles 10-52 $\mathrm{mm}$ long; blade ovate, $25-90 \times$ 14-70 mm, apex acute, sometimes obtuse, base hastate, margin entire, lobed or toothed. Flower bracts persistent; $14-24 \times 9-20 \mathrm{~mm}$. Calyx with lobes $2-7 \mathrm{~mm}$ long, lobes subuliform. Corolla with inner and outer surface of lobes and outer surface of tube white, inner surface of tube orange yellow; lobes $10-15 \times 14-23 \mathrm{~mm}$, tube $18-20 \mathrm{~mm}$ long, 4-7 $\mathrm{mm}$ in diameter. Filaments 4-7 $\mathrm{mm}$ long, anther thecae 3-5 mm long. Style 8-12 mm long, unicellular trichomes present on upper part. Fruit 15-20 $\mathrm{mm}$ long, globose base 7-10 $\mathrm{mm}$ in diameter. Seed dark brown; trichomes adhere to form ridges on testa; $2,5-4,5 \mathrm{~mm}$ in diameter.

$T$. pondoensis is found as a twiner in the undergrowth under trees in woodland. The species occurs in the Transvaal and Natal (Fig. 12).

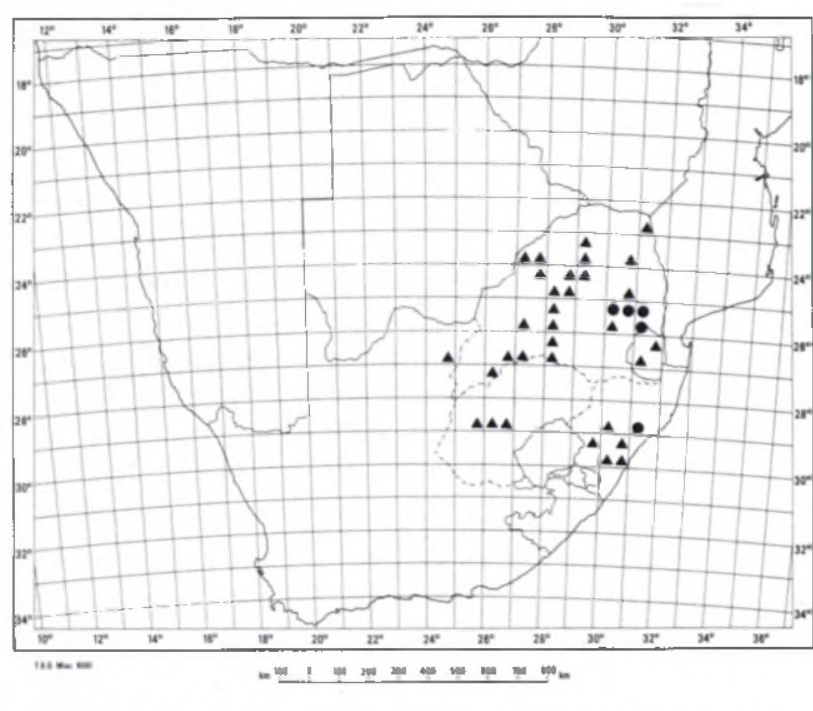

FIG. 12.- - , Thunbergia pondoensis; $\boldsymbol{\Lambda}, T$. neglecta.

Characterized by its hastate leaf base, the species flowers from December to March.

The specific epithet pondoensis refers to the area, Pondoland (eastern part of the Transkei), but the species is not known from this area. The locality given by Clarke (1912) and Wood (1909) for Wood 4015, the lectotype, is Entumeni in Natal and not Inyesane as stated on the label of the specimen in NH.

7. Thunbergia neglecta Sond in Linnaea 23: 89 (1850); Anderson in J. Linn. Soc., Bot. 7: 20 (1864); C.B. Cl. in Fl. Cap. 5,1: 9 (1912); Van der Schijff, Checklist Kruger Nat. Park 86 (1969); Ross, Fl. Natal 323 (1972); Compton, Fl. Swaz. 547 (1976). Type: Transvaal, Magaliesberg, Zeyher 1420 (Herb. Benth. K, lecto.!).

T. hirta Sond. in Linnaea 23: (1850); Lindau in Bot. Jb, 17 (Beibl. 41): 36, 38 (1893). Type: Orange Free State, Groot Vet Rivier, Zeyher 1419 (Herb. Benth. K, iso,; PRE, photo!).

T. dregeana sensu Van der Schijff, Checklist Kruger Nat. Park 86 (1969); sensu Compton, Fl. Swaz.: 546 (1976).

Scrambler, pubescent. Leaves petiolate, petioles 9-30 mm long; blade ovate, (12-) 29-47 (-57) $\times$ (13-) 20-47 (-55) $\mathrm{mm}$, apex acute, obtuse or emarginate, base cordate, margin entire, lobed or toothed. Flower bracts persistent; 11-20 × (5-) 
8-14 mm. Calyx with lobes 2-6 mm long; lobes subuliform, sometimes toothed, stipitate glands and a few unicellular trichomes present. Corolla with inner surface and outer surface of lobes and outer surface of tube dull white, inner surface of tube dull yellow; lobes 9,5-14,5 $\times 13-23 \mathrm{~mm}$; tube 17-27 $\mathrm{mm}$ long, 2-3 $\mathrm{mm}$ in diameter. Filaments $4-6 \mathrm{~mm}$ long; anther thecae 2,4-3 mm long. Style 7-12 mm long, unicellular trichomes present on upper part. Fruit $13-20 \mathrm{~mm}$ long, globose base $6-10 \mathrm{~mm}$ in diameter. Seed reddish brown; trichomes adhere together to form comb-like protuberances on testa; $3,5-5,0 \mathrm{~mm}$ in diameter.

Woodland, thornveld and grassland are natural habitats of $T$. neglecta. The plants usually occur in loam soil under trees and shrubs, but they do grow in direct sunlight between the trees and shrubs. $T$. neglecta is the only species of the genus Thunbergia occurring in the Orange Free State. It is also found in Botswana, Transvaal, Swaziland, Natal and the Cape Province (Fig. 12).

In 1850 Sonder described two new species, namely, $T$. hirta and $T$. neglecta. Anderson (1864) regarded them as conspecific and chose the epithet neglecta for the species, therefore, according to Article 57.2 of the International Code of Botanical Nomenclature (1978), his choice must be followed.

8. Thunbergia amoena $C . B$. Cl. in Fl. Cap. 5,1: 9 (1912). Type: Transvaal, Houtbosch Mountain, Nelson 498 (K, lecto.!; PRE!).

Creeper with a densely pubescent, velvet appearance. Leaves petiolate, petioles (8-) 12-48 (-65) $\mathrm{mm}$ long; blade ovate, (31-) 40-64 (-79) $\times$ (28-) 36-62 (-76) $\mathrm{mm}$, apex acute to obtuse, base cordate, margin entire or toothed. Flower bracts persistent; $14-20 \times 10-20 \mathrm{~mm}$. Calyx covered with short stipitate and pinlike glands; lobes 3-6 mm long. Corolla with inner and outer surface of lobes and outer surface of tube lemon yellow, inner surface of tube dull yellow; lobes $10-16 \times 14-17$ $\mathrm{mm}$, tube $19-29 \mathrm{~mm}$ long and $2-10 \mathrm{~mm}$ in diameter. Filaments 5-6 $\mathrm{mm}$ long, anther thecae 2,5-3,2 $\mathrm{mm}$ long. Style 11,4-13 $\mathrm{mm}$ long;

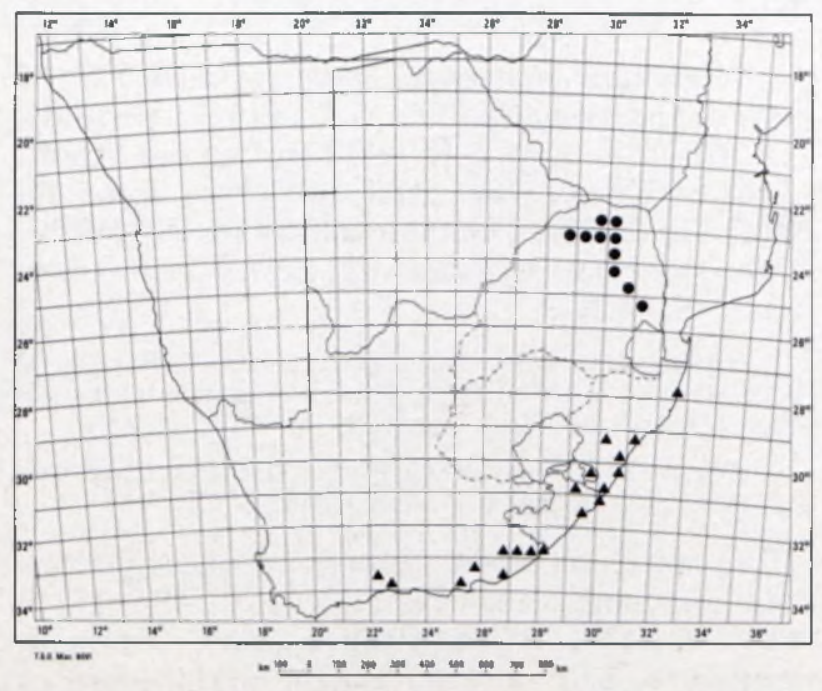

FIG. 13,- - Thunbergia amoena; $\boldsymbol{\Delta}, T$. dregeana. unicellular trichomes present on upper part. Fruit 16-18 $\mathrm{mm}$ long, globose base 6-7 $\mathrm{mm}$ in diameter; stalk 16-24 mm long. Seed brown; trichomes adhere to form ridges on surface; $3-5 \mathrm{~mm}$ in diameter.

$T$. amoena occurs mainly along the margins of inland forests, but is also found along the margins of pine plantations and against rocky slopes where the forest changes to mountain grassland. It forms dense mats on the pine needles and rocks. $T$. amoena is endemic to the Transvaal (Fig. 13).

Characteristics of $T$. amoena are the dense pubescence of the plant and the lemon-yellow colour of the corolla. The species flowers from November to February.

9. Thunbergia dregeana Nees in Linnaea 15: 352 (1841); Presl, Bot. Bemerk. 94 (1844); Nees in DC., Prodr. 11: 58 (1847); Drège in Linnaea 20: 200 (1847); Anderson in J. Linn. Soc., Bot. 7: 20 (1864); Sim, Fl. Kaffraria 60 (1894); Wood, Natal Plants 3: t.280 (1902); Wood in Trans. S. Afr. phil. Soc. 18; 203 (1909); C.B. Cl. in Fl. Cap. 5,1: 10 (1912); Bews, Fl. Natal \& Zululand 192 (1921); Fourc., Check List Flow. Pl. George, Knysna, Humansdorp \& Uniondale 6 (1941); Chittenden in Dict. Gard. 2106 (1951); Batten \& Bokelmann, Wild Flow. E. Cape 141 (1966); Ross, Fl. Natal 323 (1972); Gibson, Wild Flow. Natal t.97, f. 33 (1975); Jeppe, Natal Wild Flow. 92 (1975). Type: Cape Province, Fort Beaufort, Drège s.n. (K, lecto.!; PRE, photo!).

T. fragrans sensu E. Mey. in Drège, Zwei Pfl. Doc. 141, 226 (1843); Nees in DC., Prodr. 11: 58 (1847). Type: Cape Province, sin. loc., Eckl. 38 b (B).

Herbaceous, pubescent, creeper, Leaves petiolate, petioles (2-) $15-60 \mathrm{~mm}$ long, blade ovate, $13-53(-70) \times 14-50(-70) \mathrm{mm}$, apex acute; base cordate, margin toothed. Flower bracts caducous; 13-19 $\times$ 8-20 mm. Calyx covered with short stipitate glands; lobes 3,5-6 mm long, sometimes branched at the apex. Corolla with inner and outer surface of lobes and outer surface of tube dull orange yellow, inner surface of tube dull yellow, lobes $13-25 \times 13-27 \mathrm{~mm}$, tube $16-26 \mathrm{~mm}$ long and 2,6-6 $\mathrm{mm}$ in diameter. Filaments $4-5,7 \mathrm{~mm}$ long; anther thecae 3,6-4,6 mm long. Style $10-13 \mathrm{~mm}$ long. Fruit 15-24 $\mathrm{mm}$ long, base $7-10 \mathrm{~mm}$ in diameter; stalk (19-) 39-70 (-100) mm long. Seed greyish brown; trichomes adhere to form ridges on surface; 4-6 $\mathrm{mm}$ in diameter.

$T$. dregeana is found along streams and the margins of forests. The species occurs along the eastern coast of Natal and in the Cape Province as far south as the Gamtoos River (Fig. 13).

This species is characterized by a dull orangeyellow corolla with large lobes. It flowers from November to February. A strong decoction of $T$. dregeana is used by the Zulu people as a remedy for venereal diseases (Watt \& Breyer-Brandwijk, 1962). Medley Wood (1902) mentions that local Asian women, like the Zulus, prepare a hairwash from the green fruits of $T$. dregeana.

10. Thunbergia alata Sims in Bot. Mag. t.2591 (1825); Lodd., Bot. Cab. t.1045 (1825); Hook., 
Exot. Fl. t.177 (1827); Nees in DC., Prodr. 11: 58 (1847); Klotzsch in Peters' Reise Mossamb. 196 (1862-1864); Anderson in J. Linn. Soc., Bot. 7: 19 (1864); Lindau in Bot. Jb. 17 (beibl. 41): 40 (1893); Lindau in Engl., Pfl. Ost. Afr. C. 366 (1895); Burkhill in Fl. Trop. Afr. 5: 16 (1899); Wood, Natal Plants 3: 6, 300 (1902); C.B. Cl. in Fl. Cap. 5,1: 10 (1912); Bews, Fl. Natal \& Zululand 192 (1921); Bailey, Cycl. Hort. 3338 (1929); Chittenden in Dict. Gard. 2105 (1951); Eliovson, The Complete Gardening Book for S. Afr. 36, 131 (1960); Benoist in Fl. Madag. 182: 10 (1967); Ross, Fl. Natal 323 (1972); Kruger, Bome, Struike en Rankplante 514 (1973); Jeppe, Natal Wild Flow. 92 (1975); Plowes \& Drummond, Flow, of Rhodesia 129, t.170 (1976). Type: Zanzibar, Bojer s.n. (K, holo.!, PRE, photo!).

Herbaceous creeper; pubescent. Leaves petiolate, petioles (10-) 22-50 mm long, winged; blade ovate (16-) $21-43(-63) \times(10-) 17-32(-48) \mathrm{mm}$, apex acuminate, acute or obtuse, base cordate or hastate, margin entire or toothed. Flower bracts 13-19 $\times$ 10-16 mm. Calyx with sessile and stipitate glands. Corolla with inner and outer surface of lobes and outer surface of tube orange, inner surface of tube dark purplish black with white stripes at base; lobes 7,5-13,5 × 11-20 mm. Filaments 4-5,7 mm long; anther thecae 3,6-4,6 mm long. Style $8,5-11 \mathrm{~mm}$ long; stipitate glands present. Fruits $15-18 \mathrm{~mm}$ long, globose base 7,5-9 $\mathrm{mm}$ in diameter; stalk (13-) 35-64 mm long. Seed brown; some trichomes adhere to form wing-like protuberances; $2,4-4 \mathrm{~mm}$ in diameter.

T. alata is found along margins of forests where it is humid and the soil is humic, but also in open sunlight and more sandy soil. The species is indigenous to east Africa and occurs southwards to the eastern Transvaal and Natal (Fig. 14).

The species is characterized by the colour of the corolla, winged petioles and the trichomes of the seed surface forming wing-like protuberances. $T$. alata flowers nearly the whole year round.

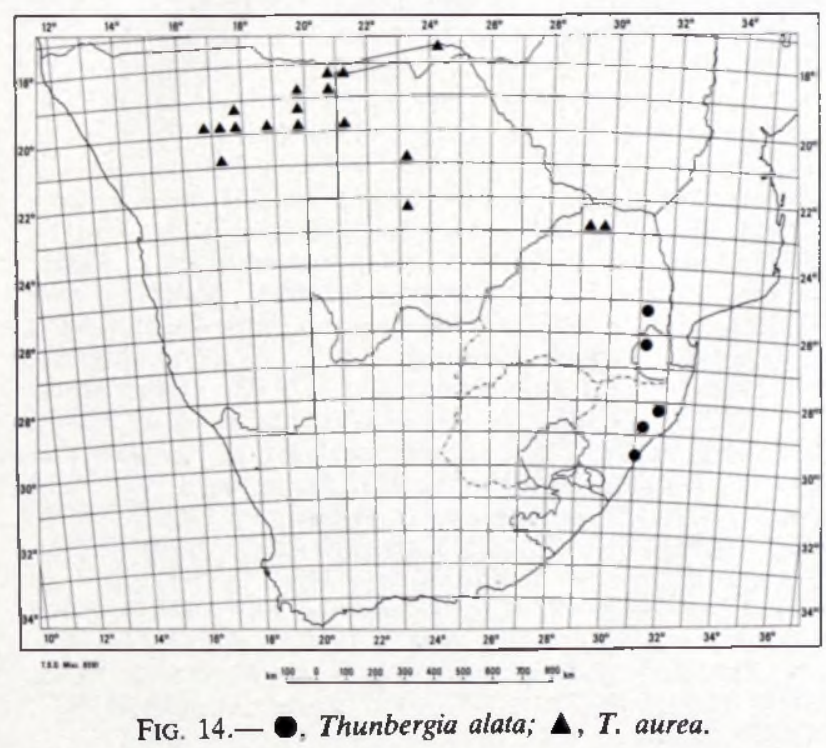

$T$. alata is known as the Black-eyed Susan, because the inner surface of the corolla tube which is usually a purplish black colour, surrounded by the bright orange corolla lobes, reminds one of an eye.

It is cultivated in many tropical and subtropical parts of the world where the species often becomes naturalized. Different colour variations occur. In 1839 Paxton described a species known as $T$. aurantiaca, darker in colour and with larger flowers than $T$. alata. The author mentions that the seed of this species cultivated in England was from the Cape of Good Hope. As far as known, only the form with flowers having an orange corolla with the inner surface of the corolla tube purplish black, is indigenous in southern Africa. Invisible ultra violet patterns on the fresh corolla of $T$. alata but visible as fluorescent patterns in pressed herbarium specimens, were observed by Eisner (1973).

11. Thunbergia aurea N.E. Br. in Kew Bull. 1909: 127 (1909); P.G. Meyer in Prodr. Fl. S.W. Afr. 129 (1968). Type: Botswana, Kwebe-Hills, Lugard 114 (K, lecto.!; PRE, photo!).

Perennial herb with erect or trailing stems, pubescent. Leaves petiolate, petioles (7-) 24-43 mm long, winged; blade lanceolate, (29-) 38-97 $(-114) ; \times(15-) 37-52(-75) \mathrm{mm}$, apex acute or acuminate, base hastate or truncate, margin entire. Flower bracts $15-21 \times 8-17 \mathrm{~mm}$, papery thin with a conspicuous venation and longer than the mature fruit. Calyx 1,4-4,2 mm long; sessile and stipitate glands as well as uni- and multicellular trichomes present. Corolla with inner and outer surface of lobes and outer surface of tube dull orange-yellow, inner surface of tube dull white; lobes $1,9-4,5 \mathrm{~mm}$ $\times 3-5,3 \mathrm{~mm}$, tube $9-17 \mathrm{~mm}$ long and $1,4-5 \mathrm{~mm}$ in diameter. Filaments $3,4-5 \mathrm{~mm}$ long, anther thecae 1,4-2 mm long. Style 5,5-6,5 mm long. Fruit $14-20$ $\mathrm{mm}$ long, globose base $6-9 \mathrm{~mm}$ in diameter; stalks (13-) 22-58 mm long; densely pubescent. Seed brown; testa distinctly visible in spaces between trichomes, trichomes adhere to form papillae-like protuberances; $2,4-4 \mathrm{~mm}$ in diameter.

$T$. aurea occurs in three of the veld types distinguished by Giess (1971) in South West Africa/Namibia, namely: (i) mountain savanna and karst veld, (ii) thorn savanna; and (iii) tree savanna and dry forest. It is found in sandy soil under trees and shrubs or against the slopes of dolomite hills. The species is also known from Botswana and the Transvaal (Fig. 14).

The species is characterized by its small size and the dull orange-yellow colour of the corolla, a winged petiole like $T$. alat $a$ and the trichomes of the seed surface adhering to form papillae-like protuberances. $T$. aurea flowers from January to March.

According to De Winter (specimen no. 4159) the leaves of $T$. aurea are used as spinach, and Rodin (specimen no. 9105) mentions that the leaves are dried and then boiled. The decoction obtained, is used as a remedy against coughing. 
IMPERFECTLY KNOWN TAXA

T. humilis Eckl, \& Zeyh., Cat. Sem. Pl. Cap.: no type.

T. capensis Retz. var. grandiflora Nees in DC., Prodr. 11: 55 (1847): the type has not been found.

T. stenophylla C.B. Cl. in Fl. Cap. 5,1: 6 (1912): the type specimen in the British Museum (Natural History) is very poor and throws no light on the identity of the taxon.

\section{UITTREKSEL}

'n Hersiening van die genus Thunbergia in suidelike Afrika is onderneem. Elf spesies word erken.

\section{REFERENCES}

ANDERSON, T., 1864. An enumeration of the species of Acanthaceae from the continent of Africa and the adjacent Islands. J. Linn. Soc., Bot. 7: 13-54.

Batten, Auriol, \& BokelmanN, Hertha, 1966. Wild flowers of the eastern Cape. Cape Town: Books of Africa.

Bor. N.L. \& RAIZADA. M.B., 1941, Some beautiful Indian climbers and shrubs. J. Bombay Nat. hist. Soc, 42: 685-697.

Clarke, C.B., 1912. Acanthaceae. In T.-Dyer, Fl. Cap. 5,1: $1-92$.

EISNER, T., 1973a. Flower markings that lure bees now seen by man. Bioscience 23: 380 .

EISNER, T, 1973b. Plant taxonomy: ultraviolet patterns of flowers visible as fluorescent patterns in pressed herbarium specimens. Science 179: 486-487.

GiEss, W., 1971. 'n Voorlopige plantegroeikaart van SuidwesAfrika. Dinteria 4: 5-114.

Hulme, MaIRN, 1954. Wild flowers of Natal. Pietermaritzburg: Shuter \& Shooter.

LINDAU, G., 1893a. Acanthaceae africanae. Bot. Jb. 17:89-113.

LINDAU, G., 1893b, Übersicht über die bisher bekannten Arten der Gattung Thunbergia L.f. Bot. Jb. 17 (bejbl. 41): 31-43.

LindaU, G., 1898. Acanthaceae africanae. Bot. Jb. 24:310-312.

LINNAEUS FIL.. C., 1781. Supplementum plantarum. Braunschweig.

Montin, L., 1773. Thunbergia. K. svenska VetenskAkad. Handl, 34: 288.

PAXton, J., 1839. Thunbergia aurantiaca. Paxt. Mag. Bot, 6:269.

Retzius, A.J., 1780. Thunbergia. Phys. Saellsk. Handl. 1: 163-164.

SONDER. W., 1850. Thunbergia hirta. Linnaea 23: 88.

SONDER, W, 1850. Thunbergia neglecta. Linnaea 23: 89.

WATt. J.M. \& BREYER-BRANDWIJK, MARIA, 1962. The medicinal and poisonous plants of southern and eastern Africa. Edinburgh: Livingstone.

WooD, J.M., 1902. Thunbergia dregeana. In J.M. Wood, Natal Plants 3, t. 280

Wood, J.M., 1909. Revised list of the Flora of Natal. Trans. S. Afr. phil. Soc. 18: 203-204.

\section{APPENDIX: SPECIMENS EXAMINED}

The specimens are listed alphabetically according to the name of the collector. The figures in brackets refer to the number of the taxon in the text.

Acocks $9898(2), 10799(7), 10966(5), \quad 11756(3), \quad 12554(4)$, 13049(3), 13298(3), 13317(9), 13584(4), 17883(4), 21962(3); Archibald 5572(4), 6083(4). Bachmann 1267(3); Bandert 41(3); Barker 1504(4), 2732(4), 2876(3), 6136(3), 7909(9); Barrett 154(3); Baur 58(3), 169(3); Bayliss 1706(3), 2518(1); Blenkiron sub J16128(3); Bokelmann 1(1); Bos 1263(8); Botha \& Van Wyk 1063(3); Bourquin \& Fakude 17(3); Bredenkamp 368(7), 526(7), 1282(7), 1308(7), 1324(7); Bremekamp \& Schweickerdt 155(7); Brever sub TRV 17895(6); Brown \& Shapiro 450(7); Buitendag 731(3), 1026(3), 1027(6); Burt Davy sub PRE 10637(3). Codd 1804(3), 4166(11), 4784(7), 6059(6), 7954(8); Codd \& De Winter 3081(1), 4950(3); Codd \& Dyer 9188(8); Coetzee 1523(3); Comins
368(9); Compton 17652(4), 17659(4), 23803(3), 27102(3), 28327(1), 28382(1), 28424(7), 30902(7); Cooper 893; Crawford 291(3), 344(3); Curson 953(11). Davidson 1591(5); Dekker 18(2); De Sousa 431(3), 506(3), 641(3); Devenish 115(3), 289(3); De Winter 2227a(7), 2911(11), 3008(11), 4187(11); De Winter \& Wiss 4159(11); Dinter 878(11), 2439(11); Dodds 70(3); Downing 598(7), 606(7); Du Plessis 614(3); Du Preez 369(3); Duthie 744(4); Dyer 4287(1). Edwards 1703(1), 1769(9), sub J17545(3); Elan-Puttick 204(3), 227(7). Fakude 89(3); Flanagan 814(4), 1130(5), 1747(9); Fourcade 3673(9). Galpin 217(4), 496(3), $1277(3), 3399(1), 7689(3), 7747(9), 9662(3), 10973(3), 11439(9)$, $12038(7), 12086(3), 12252(3), 14817(7)$, sub BOL $31279(3)$, sub BOL 31280(7), sub BOL 31282(8), sub BOL 31284(1), sub TRV 14387(7), 14770(7); Geldenhuys 601(5); Gemmell 6569(3); Germishuizen 923(3), 1711(1), 1799(3); Gerrard 1274(3); Gersiner 2506(10); Gertenbach 5076(7); Giess 9959(11); Gies \& Muller 11820(1); Giffen 812(9); Gilmore 2335(3); Goossens 1640(7); Gordon-Gray 1033(1), 1273(5). Haagner sub TRV 10749(7); Hansen 3515(7); Harrison 188(3); Hemm 304(1) Henderson, Brokenshoe \& Collins 72(9); Henrici 1693; Hilliard 4720(9); Hilliard \& Burtt 5648(5), 5920(3), 7387(3); Hitchins 78(3), 387(3), 492(3), 624(3), 881(3); Holt 208(8), 346(1); Huntey 732(1), 1363(3). Ihlenfeldt 2099(7). Jacobsen 77(1), 1195(1) $1225(3), 1664(7), 2135(7)$; Jacobsz 778(3), 1785(3); Jarman \& Guy 153(9), 208(5); Jenkins sub TRV 6752(7); Johnson 383(3), $805(4)$; Junod 2360. Kelaole A86(7); Kemsley 202(4); Kerfoot 7269(9); Kers 841(11); King 283(3), 326(3); Kinges 2955(11); Kluge 312(1), 1084(1); Krantz 6850(7); Krauss 405(3). Lang sub TRV 31081(7); Lawn 1321(1), 622(10); Leendertz 754(3), 5961(7); Lewis 4469; Liebenberg 8015(3); Lindahl 2(3); Lugard 107(11), 114(11). Maguire 2305(11); Markotter sub STE 19956(3), sub STE 19991(8); Mauve 1056(3), 4932(9); McDonald 100(3), 160(3), 421(3); Meeuse 9176(1), 9227(8), 9407(3); Meldrum 97(7) Mogg 3437(2), 8943(7), 12666(3), 13516(9); Moll 1039(3), $1487(3), 2131(3), 2141(3), 2456(9), 2853(1), 2926(9), 3100(9)$ 3218(9), 4136(7), 4728(3); Moore 12(4); Morris 776(9); Morris \& Engelbrecht 16(7); Muller 1643(7), 2063(3), 2097(1), 2206(2). Nel 227(3); Nelson 498(8); Nicholson 1714(9), 1790(9), 1801(3). Oates 94(7); Obermeyer 367(6), sub TRV 3042; Oliver 67(1), 583a(3); Olivier 1989(4); Onderstall 299(6). Papendorf 263(1); Pentz 521(9); Pole Evans 15802(3); Pooley 136(3), 1073(3); Prosser 1513(3), 1654(3). Repton 197(3), 832(7); Retief 100(3), 103(3), $104(3), 110(3), 111(3), 112(3), 116(3), 117(1), 118(10), 120(3)$ $124(3), 142(3), 151(7), 152(3), 154(1), 163(8), 164(3), 178(8)$ $179(3), 180(1), 182(8), 189 \mathrm{a}(1), 190(3), 190 \mathrm{a}(3), 191(3), 192(3)$, $200(3), 201(9), 205(3), 209(3), 210(3), 212(3), 213(5), 214(3)$ $215(3), 217(3), 218(5), 220(1), 222(3), 227(3), 228(1), 236(3)$, 237(3), 244(9), 245(9), 254(4), 862(9), 1143(6); Retief \& Herman 126(7); Rodin 9105(11); Rogers 198(4), 18042(8), 18951(8), sub BOL 11738: Ross 1468(3); Ross \& Moll 2271(9); Rudatis 27(3), 479(1), sub STE 2397(5); Rump sub NH 20323(2). Salberg 10(3) Sandeman sub NU 58797; Sanderson 442(5); Scheepers 89(8), 850(3), 1033(1); Schlechter 2908(2), 6561(3), 21342(7); Schlieben 9382(3), 9551(10); Schlieben \& Strey 8301(8); Schonland 3820(4), 3903(3); Schweickerdt 971(3); Seydel 2149(11); Shirley 169(3), sub NU 31686(3); Sidey 131(3); Sim 1391(4); Smuts 380(7), 394(3); Smuts \& Gillett 3053(7), 3219(8), 3393(3); Stephen 2631(7); Stewart 112(3); Steynberg 724(8); Stirton 111(3), 347(2), 376(3), $727(3), 1010(3), 1023(3), 1025(3), 1092(3), 1095(3), 1103(3)$, $1128(3), 1116(3), 1135(3), 1136(3), 1137(3), 1209(3), 1211(3)$, $1215(3), 1218(2), 1220(3), 1232(2), 1245(2), 1261(3), 1277(3)$, $1302(3), 1318(3), 1327(3), 1347(3), 1349(3), 1354(3), 1360(3)$, $1370(3), 1380(3), 1386(3), 1399(3), 1425(1), 1435(1), 1714(3)$, $1734(3), 5143(3), 5615(3)$; Story 585(3), 4985(3), 6305(3); Strey $4195(5), 4300(9), 5060(9), 5620(3), 6208(1), 6403(3), 7131(1)$ $8015(3), 9192(1), 9392(3), 9418(1)$; Sutton 8103(3). Taylor 5253(3); Theron 1078(3), 1598(9), 1797(9), 1993(1); Thode A273(1), sub STE 2745(10); Thunberg sub Herb. Thunb. 14601; Tyson 1206(3), 2559(9). Vahrmeijer 607(9), 1577(7); Vahrmeijer \& du Preez 2495(11); Vahrmeijer \& Tölken 277(3); Van der Schijff $8(1), 1222(7), 3255(7), 5895(1), 5916(1) ;$ Van der Walt 321(3); Van Greuning 263(11); Van Hoepen 1738(3); Van Jaarsveld 1079(8), 1098(6); Van Vuuren 1332(3), 1835(3); Van Wyk 1402(7), 5094(1); Verdoorn 140(3). Walters sub PRE 10759(7); Ward 571(9), 942(9), 3517(7); Watmough 402(9); Wells 2018(3), 3124(4); Werdermann \& Oberdieck 1738(7), 2013(7), 2124(1); Wild \& Drummond 6971(11); Williams sub TRV 7677(7); Wood $1(3), 284(1), 543(9), 643(2), 696(2), 1218(5), 4015(6), 6376(9)$, sub SAM 18933; Wylie sub NH 28009(2), sub Wood 8478. Young $303(3), 372(1), 489(3)$, A 545, A 655. Zeyher 1418(3), 1419(7), 1420(7); Zwanziger 686(11). 